\title{
Weight Gain during Systemic Oncologic Therapy for Breast Cancer: Changes in Food Intake and Physical Activity
}

doi: https://doi.org/10.32635/2176-9745.RBC.2019v65n2.360

\author{
Ganho Ponderal durante o Tratamento Oncológico Sistêmico para Câncer de Mama: Mudanças na Ingestão Alimentar e na \\ Atividade Física \\ Aumento de Peso durante el Tratamiento Oncológico Sistémico para Cáncer de Mama: Cambios en la Ingestión de \\ Alimentos y Actividad Física
}

\author{
Marco Aurélio da Silva Ribeiro-Sousah'; Isabelle Mastelaro²; Fernanda Maris Peria ${ }^{3}$; Hélio Angotti Carrara ${ }^{4}$; Jurandyr Moreira de \\ Andrade $^{5}$; Selma Freire de Carvalho Cunha ${ }^{6}$
}

\begin{abstract}
Introduction: Weight gain frequently occurs during treatment for breast cancer. Objective: To evaluate changes in dietary intake and physical activity in the weight evolution of women on systemic oncologic treatment for breast cancer. Method: The prospective and comparative study included 89 women submitted to systemic oncologic treatment for breast cancer, grouped according to the occurrence of weight gain in relation to body weight documented before beginning treatment. Patients were classified as 1) Group with weight gain (those with an increase in body weight greater than or equal to $2 \%$ over pre-treatment weight); 2) Group without weight gain (those who maintained or lost weight during treatment). We calculated body mass index (BMI) of patients and analyzed their body composition by bioelectrical impedance (BIA). Changes in food intake, gastrointestinal symptoms, and physical activity level, as well as reductions in muscle and fat mass, were documented. Results: Tumor staging $(\mathrm{p}=0.24)$, use of antineoplastic drugs $(\mathrm{p}=0.23)$ and intention of treatment $(\mathrm{p}=0.61)$ were no different between the weight gain group $(\mathrm{n}=36)$ and no weight gain group $(\mathrm{n}=53)$. No difference was found in anthropometric and BIA data between the groups during oncologic treatment. Frequency of gastrointestinal symptoms was not different between the groups. However, increased food intake and bed rest, and a decrease in physical activity level were more frequent among women who gained weight during therapy. Conclusions: Weight gain in women undergoing systemic oncologic therapy for breast cancer may be, at least in part, caused by higher energy intake and lower physical activity. Key words: Breast Neoplasms/therapy; Weight Gain; Eating; Exercise.
\end{abstract}

\section{Resumo}

Introduçáo: $\mathrm{O}$ ganho ponderal ocorre com frequência durante o tratamento oncológico para o câncer de mama. Objetivo: Avaliar as mudanças da ingestão alimentar e da atividade física na evolução ponderal de mulheres sob tratamento oncológico sistêmico para câncer de mama. Método: Estudo prospectivo e comparativo que incluiu 89 mulheres submetidas a tratamento oncológico sistêmico para neoplasia mamária, agrupadas de acordo com a ocorrência de aumento ponderal em relação ao peso corporal documentado antes do início do tratamento. As pacientes foram classificadas em 1) Grupo com ganho ponderal (aumento $\geq 2 \%$ em relação ao peso pré-tratamento); 2) Grupo sem ganho ponderal (ganho ou manutenção do peso durante o tratamento). $\mathrm{O}$ índice de massa corporal foi calculado e a composição corporal foi determinada por impedância bioelétrica. Foram documentadas mudanças na ingestão de alimentos e no padrão de atividade física, queixas digestivas e alteraçôes da massa corporal muscular e adiposa. Resultados: Os grupos com ganho ponderal $(n=36)$ e sem ganho ponderal $(n=53)$ foram semelhantes quanto ao estadiamento tumoral $(p=0,24)$, emprego das classes de drogas antineoplásicas $(p=0,23)$ e modalidade de tratamento oncológico $(\mathrm{p}=0,61)$. Durante o tratamento oncológico sistêmico, a composição corporal foi semelhante entre os grupos de estudo. Comparadas com o grupo sem ganho de peso, houve maior proporção de aumento na ingestão alimentar e de restrição na atividade física entre as mulheres que ganharam peso. Conclusáo: $\mathrm{O}$ ganho ponderal em mulheres com neoplasia mamária em tratamento oncológico sistêmico pode ser atribuído à maior ingestão energética e à reduçáo na atividade física.

Palavras-chave: Neoplasias da Mama/terapia; Ganho de Peso; Ingestão de Alimentos; Exercício.
Resumen

Introducción: El aumento de peso es frecuente durante el tratamiento oncológico para el cáncer de mama. Objetivo: Evaluar los cambios de la ingesta alimentaria y de la actividad física en la evolución ponderal de las mujeres en tratamiento oncológico sistémico para el cáncer de mama. Método: El estudio prospectivo y comparativo incluyó 89 mujeres sometidas a tratamiento sistémico oncológico por neoplasia mamaria, agrupadas de acuerdo con la ocurrencia de aumento ponderal en relación al peso corporal al início del tratamiento. Las pacientes fueron clasificadas en 1) Grupo con ganancia ponderal ( $\geq 2 \%$ en relación al peso pretratamiento); 2) Grupo sin ganancia ponderal (mantenimiento o pérdida de peso durante el tratamiento). El índice de masa corporal fue calculado y la composición corporal fue determinada por impedancia bioeléctrica. Fueron documentadas las variaciones en la ingestión de alimentos y el patrón de actividad física, quejas digestivas y redución en la masa corporal. Resultados: Los grupos con ganancia ponderal $(n=36)$ y sin ganancia ponderal $(n=53)$ fueron semejantes cuanto a estadificación tumoral $(\mathrm{p}=0,24)$, empleo de medicamentos antineoplásicos $(\mathrm{p}=0,23)$ y modalidad del tratamiento oncológico $(\mathrm{p}=0,61)$. Durante el tratamiento oncológico, la composición corporal fue semejante entre los grupos de estudio. Comparados con el grupo sin aumento de peso, se observó aumento en la ingestión de alimentos y restricción en la actividad física entre las mujeres que ganaron peso. Conclusión: El aumento de peso en mujeres sometidas a tratamiento oncológico para cáncer de mama, puede ser atribuido a mayor ingestión energética y reducción de actividad física.

Palabras clave: Neoplasias de la Mama/terapia; Aumento de Peso; Ingestión de Alimentos; Ejercicio.

${ }^{1}$ Ribeirão Preto Medical School, São Paulo University. Ribeirão Preto (SP), Brazil. Orcid iD: https://orcid.org/0000-0003-0995-7258

${ }^{2}$ Ribeirão Preto Medical School, São Paulo University. Ribeirão Preto (SP), Brazil. Orcid iD: https://orcid.org/0000-0003-2090-6574

${ }^{3}$ Ribeirão Preto Medical School, São Paulo University. Ribeirão Preto (SP), Brazil. Orcid iD: https://orcid.org/0000-0001-5133-165X

${ }^{4}$ Ribeirão Preto Medical School, São Paulo University. Ribeirão Preto (SP), Brazil. Orcid iD: https://orcid.org/0000-0003-1477-2805

${ }^{5}$ Ribeirão Preto Medical School, São Paulo University. Ribeirão Preto (SP), Brazil. Orcid iD: https://orcid.org/0000-0003-3619-0582

${ }^{6}$ Ribeirão Preto Medical School, São Paulo University. Ribeirão Preto (SP), Brazil. Orcid iD: https://orcid.org/0000-0002-4092-4502

Correspondent address: Marco Aurélio da Silva Ribeiro-Sousah. Avenida Bandeirantes, 3900 - Monte Alegre. Ribeirão Preto (SP), Brazil. 14049-900. Email: marcoas@hcrp.usp.br 


\section{INTRODUCTION}

Breast cancer is the leading cause of cancer mortality in young and adult women ${ }^{1}$. It has been demonstrated that the incidence of breast cancer is associated with several risk factors, including high body weight and tumor-specific subtype ${ }^{2}$. Higher levels of adiposity at the time of or soon after breast cancer diagnosis are associated with poor prognosis ${ }^{3}$, increased local recurrence ${ }^{4}$, more complications related to surgery and radiation ${ }^{4}$, second primary malignancies ${ }^{5}$ and cardiovascular disease mortality ${ }^{6}$.

Substantial weight gain may occur in a high percentage of patients receiving systemic therapy for breast cancer ${ }^{7,8}$, although their resting energy expenditure is similar when compared to healthy women'. In a recent meta-analysis, weight gain was more pronounced in papers published until 2000 and has been associated with chemotherapy regimen antineoplastic using cyclophosphamide, methotrexate and, 5 -fluorouracil ${ }^{10}$. Although weight gain during chemotherapy has decreased over time, weight gain etiology is not well understood, and it deserves clinical attention. The purpose of this study was to evaluate changes in dietary intake and physical activity in the weight evolution of women on systemic oncologic treatment for breast cancer.

\section{PATIENTS AND METHODS}

This prospective, descriptive and comparative study was approved by the local Institutional Review Board (approval number 712449) and conducted in an outpatient Chemotherapy Unit of a public university hospital from March to October 2017.

\section{SUBJECTS}

Data were collected from a convenience sample of adult women before beginning systemic therapy for breast cancer, independent of the histological type of breast cancer, tumor staging, and class of antineoplastic drugs. We excluded women who were receiving treatment for less than three months, women with second primary malignancies, cardiac pacemaker, and those with Karnofsky Performance Status below 60\% ${ }^{11}$. Patients with physical, cognitive, or emotional disabilities that could hinder communication were excluded.

\section{ONCOLOGICAL DATA}

An oncologist obtained data on breast cancer stage and the antineoplastic drug from electronic medical records (Table 1) The Union for International Cancer Control (UICC) protocol was used to classify pretreatment clinical stage $(\mathrm{cTNM})^{12}$. Systemic therapy was conducted according to standard protocols ${ }^{13,14}$, which consider the cTNM, the performance status and the expression of three biomarkers: estrogen receptor (ER), progesterone receptor (PR), and human epidermal growth factor receptor 2 (HER2). Based on their mechanism of action, the antineoplastic drugs were classified in four therapeutic classes: a) monoclonal antibodies (trastuzumab); b) taxanes (docetaxel and paclitaxel); c) anthracyclines (combinations with doxorubicin or epirubicin) and d) platin (cisplatin or carboplatin). All

Table 1. Comparison of demographic data, clinical stage, intention of treatment, and class of oncologic drugs between women who gained weight (weight gain group) and those who did not gain weight (no weight gain group) during systemic oncological treatment for breast cancer

\begin{tabular}{|c|c|c|c|}
\hline & $\begin{array}{l}\text { Weight gain group } \\
\qquad(n=36)\end{array}$ & $\begin{array}{l}\text { No weight gain group } \\
\qquad(n=53)\end{array}$ & p value \\
\hline \multicolumn{4}{|l|}{ Demographic data } \\
\hline Age [years; median $(95 \% \mathrm{Cl})]$ & $49.7(45.9-53.5)$ & $49.1(46.0-52.2)$ & 0.69 \\
\hline Patients > 65 years old $(n, \%)$ & $4(11.1)$ & $5(9.4)$ & 0.80 \\
\hline \multicolumn{4}{|l|}{ Clinical TNM staging $(n, \%)$} \\
\hline I & $4(11.1)$ & $1(1.9)$ & \multirow{4}{*}{0.24} \\
\hline II & $13(36.1)$ & $19(35.8)$ & \\
\hline III & $7(19.4)$ & $16(30.2)$ & \\
\hline IV & $12(33.3)$ & $17(32.1)$ & \\
\hline \multicolumn{4}{|l|}{ Intention of treatment (n, \%) } \\
\hline Neoadjuvant/Adjuvant & $24(66.7)$ & $38(71.7)$ & \multirow{2}{*}{0.61} \\
\hline Palliative & $12(33.3)$ & $15(28.3)$ & \\
\hline \multicolumn{4}{|l|}{ Class of oncologic drugs $(n, \%)$} \\
\hline Monoclonal antibodies & $14(38.9)$ & $13(24.5)$ & \multirow{4}{*}{0.23} \\
\hline Taxanes & $11(30.6)$ & $17(32.1)$ & \\
\hline Anthracyclines & $8(22.2)$ & $21(39.6)$ & \\
\hline Platin & $3(8.3)$ & $2(3.8)$ & \\
\hline
\end{tabular}


patients received intravenous dexamethasone $(10 \mathrm{mg}$ diluted with physiological saline) in compliance with antiemetic and desensitization protocols. The ones treated with taxanes and anthracyclines were also given dexamethasone $(8 \mathrm{mg})$ orally one day before and two days after administration of the antineoplastic drug, because of the risk of vomiting. Patients in stage I, II or III and good performance status were submitted from six to eight chemotherapy cycles (neo/ adjuvant) according to the treatment protocols. Patients with HER-2 protein overexpression received chemotherapy followed by monoclonal antibody for 17 cycles (around 12 months). The ones in stage IV received multiple lines of chemotherapy, according to the response to and toxicity of the treatment.

\section{NUTRITIONAL ASSESSMENT}

A registered dietitian collected the data. For each volunteer, height and weight were documented on two occasions: 1) before beginning treatment; 2) during systemic oncological treatment, on the same day the nutrition protocol was applied. Body weight was measured on an electronic scale for adults (Welmy ${ }^{\oplus}$ W200), with an accuracy of $100 \mathrm{~g}$ and maximum capacity of $200 \mathrm{~kg}$. Patients were weighed standing up straight, barefoot and with minimal clothing. The weight change was calculated by the difference between the weight obtained before beginning cancer treatment. Weight gain was defined as an increase of more than $2 \%$ in body weight in relation to the weight before beginning treatment.

Height was measured using a $2.0 \mathrm{~m}$ stadiometer and accuracy of $0.5 \mathrm{~cm}$. Body mass index $\left(\mathrm{BMI}, \mathrm{kg} / \mathrm{m}^{2}\right)$ was classified according to the World Health Organization classification ${ }^{15}$ for adult women and the Pan American Health Organization criteria ${ }^{16}$ for elderly women. Bioelectrical Impedance Analysis (BIA) was performed using Quantum BIA $101^{\circ}$ Q-RJL System (Michigan, USA), according to standard techniques.

Patients were asked about changes in recent food intake in comparison to usual intake before the therapy. We applied a questionnaire about gastrointestinal symptoms - hyporexia, early satiety, dysgeusia, xerostomia, lesions in the oral cavity, nausea, vomiting, dysphagia or odynophagia, diarrhea and obstipation - lasting at least two weeks. Changes in functional capacity were assessed by self-reported daily physical activity. In addition, muscle wasting, subcutaneous fat loss and edema were evaluated by physical examination.

\section{StATISTICAL ANALYSIS}

Data analyses were performed using Statistica software (version 8.0; StatSoft Inc, Tulsa, OK, USA) and statistical significance was set at $\mathrm{p}<0.05$. Quantitative variables were expressed as geometric mean and $95 \%$ confidence intervals (95\%CI); comparisons between groups were assessed by the Mann-Whitney test. Yates Chi-square test was used to compare categorical variables.

\section{RESULTS}

Eighty-nine women participated voluntarily in this study. The patients were classified in "weight gain" group $(n=36)$ or "no weight gain" group $(n=53)$, which included both patients who maintained and those who lost weight after the beginning of the therapy. In the weight gain group, weight increase from usual weight was $8.1 \%$ (95\% CI 4.9-11.4). In the no weight gain group, 36\% of women lost weight and $64 \%$ maintained body weight during oncological treatment. There were no statistical differences in systemic therapy duration $[18.1$ (95\% CI 7.2-29.0) vs. 11.4 (95\% CI 5.8-17.0) months, $\mathrm{p}=0.07]$ and concurrent radiotherapy (5.6 vs. $1.9 \%, p=0.35$ ) between weight gain group and no weight gain group, respectively. The number of patients under palliative treatment (33.3 vs. $28.3 \%, \mathrm{p}=0.63 \%$ ) was not different between the groups.

Sixty-three women $(71 \%)$ had BMI above normal range before systemic oncological treatment $(36 \%$ overweight and 35\% obesity) (Table 2). The weight gain group showed lower weight [69.8 kg (95\% CI 63.4-76.2) vs. $75.2 \mathrm{~kg}(95 \% \mathrm{CI} 70.8-79.6), \mathrm{p}=0.06]$ and BMI [27.8 $\mathrm{kg} / \mathrm{m}^{2}(95 \%$ CI $25.5-30.1)$ vs. $29.4 \mathrm{~kg} / \mathrm{m}^{2}(95 \%$ CI $27.8-$ 31.0), $\mathrm{p}=0.09$ ] before treatment compared with the no weight gain group, but this difference was not statistically significant. There was no difference in weight $[75.1 \mathrm{~kg}$ (95\% CI 68.5-81.6) vs. $73.8 \mathrm{~kg}$ (95\% CI 69.0-78.7), $\mathrm{p}=0.93]$, BMI [29.9 kg/m² (95\% CI 27.6-32.2) vs. 28.9 $\mathrm{kg} / \mathrm{m}^{2}$ (95\% CI\% 27.1-30.7), $\left.\mathrm{p}=0.70\right]$, fat-free mass [65.3\% (95\% CI 62.6-67.9) vs. $66.0 \%$ (95\% CI 64.167.8), $\mathrm{p}=0.91]$ and fat mass [34.6\% (95\% CI 31.9-37.3) vs. $33.9 \%$ (95\% CI 32.0-35.8), $\mathrm{p}=0.91$ ] between women in the weight gain group and no weight gain group during the oncological treatment, respectively (Table 2).

Reduction in food intake was more frequent $(\mathrm{p}=$ $0.02)$ in the no weight gain group (13.9 vs. $26.4 \%)$, whereas increase in food intake was more frequent in the weight gain group (80.6 vs. 52.8\%) (Table 3). However, the frequency of gastrointestinal symptoms, muscle wasting, subcutaneous fat loss and fluid retention was not different between the groups. Bed rest and restricted physical activity were more frequent $(\mathrm{p}<0.01)$ among women with weight gain $(86.1$ vs. $58.5 \%)$. On the other hand, a higher percentage of women without weight gain showed none or little change in physical activity (13.8 vs. 41.5\%) (Table 3). 
Table 2. Body composition (median and 95\% Cl) of women who gained weight (weight gain group) and those who did not gain weight (no weight gain group) at the time of diagnosis and during systemic oncological treatment for breast cancer

\begin{tabular}{|c|c|c|c|}
\hline & $\begin{array}{l}\text { Weight gain group } \\
\qquad(n=36)\end{array}$ & $\begin{array}{l}\text { No weight gain group } \\
\qquad(\mathrm{n}=53)\end{array}$ & $p$ value \\
\hline \multicolumn{4}{|l|}{ Pretreatment } \\
\hline Weight (kg) & $69.8(63.4-76.2)$ & $75.2(70.8-79.6)$ & 0.06 \\
\hline BMI $\left(\mathrm{kg} / \mathrm{m}^{2}\right)$ & $27.8(25.5-30.1)$ & $29.4(27.8-31.0)$ & 0.09 \\
\hline \multicolumn{4}{|l|}{ BMI classification } \\
\hline Low/normal weight (n, \%) & 14 (38.9) & $12(22.6)$ & 0.10 \\
\hline Overweight/obesity ( $n, \%)$ & $22(61.1)$ & $41(77.4)$ & \\
\hline \multicolumn{4}{|l|}{ During treatment } \\
\hline Weight (kg) & $75.1(68.5-81.6)$ & $73.8(69.0-78.7)$ & 0.93 \\
\hline BMI $\left(\mathrm{kg} / \mathrm{m}^{2}\right)$ & $29.9(27.6-32.2)$ & $28.9(27.1-30.7)$ & 0.70 \\
\hline \multicolumn{4}{|l|}{ BMI classification } \\
\hline Low/normal weight (n, \%) & $9(25.0)$ & $14(26.4)$ & 0.88 \\
\hline Overweight/obesity (n, \%) & $27(75.0)$ & $39(73.6)$ & \\
\hline \multicolumn{4}{|l|}{ BIA } \\
\hline Fat-free mass (\%) & $65.3(62.6-67.9)$ & $66.0(64.1-67.8)$ & 0.91 \\
\hline Fat mass (\%) & $34.6(31.9-37.3)$ & $33.9(32.0-35.8)$ & 0.91 \\
\hline Total body water (L) & $37.9(35.6-40.3)$ & $36.4(34.8-38.0)$ & 0.40 \\
\hline
\end{tabular}

BMI: body mass index; BIA: Bioelectrical Impedance Analysis

Table 3. Prevalence of changes in food intake, gastrointestinal symptoms, and functional capacity, loss of muscle and fat mass, and edema in women who gained weight (weight gain group) and those who did not gain weight (no weight gain group) during chemotherapy for breast cancer

\begin{tabular}{|c|c|c|c|}
\hline & $\begin{array}{l}\text { Weight gain group } \\
\qquad(n=36)\end{array}$ & $\begin{array}{l}\text { No weight gain group } \\
\qquad(n=53)\end{array}$ & $p$ value \\
\hline \multicolumn{4}{|l|}{ Food intake } \\
\hline Less than usual $(\mathrm{n}, \%)$ & 5 (13.9) & $14(26.4)$ & \multirow{3}{*}{0.02} \\
\hline Unaltered (n, \%) & $2(5.6)$ & $11(20.7)$ & \\
\hline More than usual (n, \%) & $29(80.6)$ & $28(52.8)$ & \\
\hline \multicolumn{4}{|l|}{ Gastrointestinal symptoms } \\
\hline Hyporexia $(n, \%)$ & $7(19.4)$ & $16(30.2)$ & 0.25 \\
\hline Early satiety (n, \%) & $11(30.6)$ & $24(45.3)$ & 0.16 \\
\hline Dysgeusia $(n, \%)$ & $22(61.1)$ & $34(64.1)$ & 0.77 \\
\hline Xerostomia (n, \%) & $26(72.2)$ & $30(56.6)$ & 0.13 \\
\hline Lesions in oral cavity (n, \%) & $17(47.2)$ & $28(52.8)$ & 0.60 \\
\hline Nausea $(n, \%)$ & $26(72.2)$ & $39(73.6)$ & 0.89 \\
\hline Vomiting (n, \%) & $18(50.0)$ & $24(45.3)$ & 0.66 \\
\hline Dysphagia/odynophagia (n, \%) & $11(30.6)$ & $10(18.9)$ & 0.20 \\
\hline Diarrhea (n, \%) & $8(22.2)$ & $14(26.4)$ & 0.65 \\
\hline Obstipation (n, \%) & $13(36.1)$ & $19(35.8)$ & 0.98 \\
\hline \multicolumn{4}{|l|}{ Functional capacity } \\
\hline Bed rest and restricted physical activity $(n, \%)$ & $31(86.1)$ & $31(58.5)$ & \multirow{2}{*}{$<0.01$} \\
\hline None or little change in physical activity ( $n, \%)$ & $5(13.8)$ & $22(41.5)$ & \\
\hline \multicolumn{4}{|l|}{ Physical examination } \\
\hline Moderate or severe muscle wasting ( $\mathrm{n}, \%)$ & $6(16.7)$ & $12(22.6)$ & 0.49 \\
\hline Moderate or severe subcutaneous fat loss ( $n, \%)$ & $14(38.9)$ & $19(35.8)$ & 0.77 \\
\hline Moderate or severe edema (n, \%) & $22(61.1)$ & $26(49.1)$ & 0.26 \\
\hline
\end{tabular}

\section{DISCUSSION}

The present study documented weight gain in $40 \%$ of women with breast cancer during systemic therapy. However, these patients had lower body weight and BMI before the oncological treatment, and consequently, these parameters were not different between the groups after the therapy. Our findings were consistent with those reporting that weight gain is common during chemotherapy for breast cancer ${ }^{9,17-20}$. In addition, our results concur with 
those showing an inverse relationship between body weight at breast cancer before beginning treatment and subsequent weight gain ${ }^{21,22}$. However, a previous study reported that there were no changes in the percentage of body fat assessed by BIA in women during chemotherapy for breast cancer (stage I to IIIA) compared to baseline values $^{23}$.

Increase in food intake was more frequent in our patients that gained weight during the systemic therapy. Our study concurs with a previous work reporting that twenty-five percent of patients showed increased appetite during chemotherapy ${ }^{23}$ that resulted in higher energy intake than documented in healthy women ${ }^{24}$. Aversion to animal protein, especially meat, is described during chemotherapy for breast cancer ${ }^{25}$. Despite the lower intake of protein and fat, there was an increase in carbohydrate consumption, which implies in a higher energy intake ${ }^{24}$. In this study, the frequency of gastrointestinal symptoms was not different between the groups. Dysgeusia occurs among patients undergoing neoplastic treatment ${ }^{26}$, which potentially affects food intake and appetite. However, it is not clear which patients are more prone to taste alterations in a way that negatively affects food intake ${ }^{27}$. Nausea and vomiting were common complaints in our groups of study (72 and $73 \%$ ), with a higher prevalence than that documented in a prospective observational study of breast cancer patients treated with anthracycline plus cyclophosphamide (63 and 25.4\%) ${ }^{28}$.

In the present study, bed rest and restricted physical activity were more prevalent among women with weight gain in comparison with those who maintained or lost weight after the beginning of oncological treatment. Weight gain during chemotherapy has been reported to be associated with reduction in fat-free body mass ${ }^{23}$. Fatigue during and after oncologic treatment can imply in lower physical activity as a manifestation of impairment of nutritional status ${ }^{29}$. Duration and intensity of fatigue correlate positively with BMI and may be a clinical manifestation of a pro-inflammatory state due to excessive body fat ${ }^{30,31}$.

The present study has some limitations. Our patients were not submitted to psychological evaluation. Some people may eat more in response to psychological distress associated with a recent diagnosis of cancer ${ }^{17}$. Also, we did not analyze changes in body weight ascribed to menopause ${ }^{20}$. Serial BIA measurements could provide additional information on fat mass changes in our subgroup of women who gained weight. One may question whether weight gain in our patients was related to increase in total body water; however, no difference was found in this measure obtained by BIA or physical examination. Likewise, weight gain was probably not caused by water retention or increased appetite related to corticosteroids, since both groups received a low-dose dexamethasone for a short term.

In our study, it is possible that energy intake control counseling has been made only for those women with higher body weight at the beginning of breast cancer treatment. Previous studies have suggested that women should be advised to prevent weight gain during breast cancer treatment, even those with adequate body weight at the time of diagnosis ${ }^{17}$. Dietary recommendations include the intake of a micronutrient-rich diet, low in simple carbohydrates and total fats $s^{32,33}$. In addition to helping to prevent weight gain, regular physical activities may reduce common side effects of breast cancer therapy, such as fatigue, depression and decreased muscle strength ${ }^{34}$, since nutritional counseling alone in women who were undergoing treatment for breast cancer did not prevent weight gain ${ }^{17}$. Our data are in line with others suggesting the need for a multi-professional approach that included cognitive behavioral therapy, dietary counseling and physical activity ${ }^{35}$.

In conclusion, weight gain in breast cancer patients undergoing systemic therapy seems to be caused, at least in part, by increased energy intake and reduced physical activity. Future studies evaluating longitudinal measurements of dietary intake and body composition are needed to confirm these findings.

\section{CONTRIBUTIONS}

Marco Aurélio da Silva Ribeiro-Sousah, Fernanda Maris Peria, Hélio Angotti Carrara, Jurandyr Moreira de Andrade and Selma Freire de Carvalho Cunha participated of the study design, data collection, analysis and interpretation, wording and critical review with intellectual input. Isabelle Mastelaro participated of the study design, data collection, analyses and interpretation. All the authors approved the version for publication.

\section{CONFLICT OF INTEREST}

None.

\section{FUNDING SOURCES}

None.

\section{REFERENCES}

1. Siegel RL, Miller KD, Jemal A. Cancer statistics, 2017. CA Cancer J Clin. 2017;67(1):7-30. doi: https://doi. org/10.3322/caac.21387. 
2. Miyagawa Y, Miyake T, Yanai A, et al. Association of body mass index with risk of luminal A but not luminal $B$ estrogen receptor-positive and HER2-negative breast cancer for postmenopausal Japanese women. Breast Cancer. 2015;22(4):399-405. doi: https://doi. org/10.1007/s12282-013-0493-z.

3. Papa AM, Pirfo CBL, Murad AM, et al. Impacto da obesidade no prognóstico do câncer de mama. Rev Bras Oncol Clín. 2013;9(31):25-30.

4. Lee K, Kruper L, Dieli-Conwright CM, Mortimer JE. The Impact of Obesity on Breast Cancer Diagnosis and Treatment. Curr Oncol Rep. 2019;21(5):41. doi: https:// doi.org/10.1007/s11912-019-0787-1.

5. Pfeiffer RM, Park Y, Kreimer AR, et al. Risk prediction for breast, endometrial, and ovarian cancer in white women aged 50 y or older: derivation and validation from population-based cohort studies. PLoS Med. 2013;10(7):e1001492. doi: https://doi.org/10.1371/ journal.pmed.1001492.

6. Bradshaw PT, Stevens J, Khankari N, Tet al. Cardiovascular disease mortality among breast cancer survivors. Epidemiology. 2016;27(1):6-13. doi: https:// doi.org/10.1097/EDE.0000000000000394.

7. Schvartsman G, Gutierrez-Barrera AM, Song J, et al. Association between weight gain during adjuvant chemotherapy for early-stage breast cancer and survival outcomes. Cancer Med. 2017;6(11):2515-22. doi: https://doi.org/10.1002/cam4.1207.

8. Vagenas D, DiSipio T, Battistutta D, et al. Weight and weight change following breast cancer: evidence from a prospective, population-based, breast cancer cohort study. BMC Cancer 2015;15:28. doi: https://doi. org/10.1186/s12885-015-1026-2.

9. Zuconi CP, Ceolin Alves AL, Toulson Davisson Correia MI. Energy expenditure in women with breast cancer. Nutrition. 2015;31(4):556-9. doi: https://doi. org/10.1016/j.nut.2014.05.009.

10. van den Berg MM, Winkels RM, de Kruif JT, et al. Weight change during chemotherapy in breast cancer patients: a meta-analysis. BMC Cancer. 2017;17(1):259. doi: https://doi.org/10.1186/s12885-017-3242-4.

11. Crooks V, Waller S, Smith T, et al. The use of the Karnofsky Performance Scale in determining outcomes and risk in geriatric outpatients. J Gerontol. 1991;46(4):M139-44.

12. Amin MB, Greene FL, Edge SB, et al. The eighth edition AJCC cancer staging manual: continuing to build a bridge from a population-based to a more "personalized" approach to cancer staging. CA Cancer J Clin. 2017;67(2):93-99. doi: https://doi.org/10.3322/caac.21388.

13. National Comprehensive Cancer Network (U.S.). NCCN Clinical Practice Guidelines in Oncology [Internet]. Version 1. Plymouth Meeting: NCCN; 2016. [cited 2018 Jul 12]. Available from: https:/www.nccn. org/professionals/physician_gls/default.aspx\#site.
14. Santa-Maria CA, Gradishar WJ. Changing treatment paradigms in metastatic breast cancer: lessons learned. JAMA Oncol. 2015;1(4):528-534. doi: https://doi. org/10.1001/jamaoncol.2015.1198.

15. World Health Organization. Obesity: preventing and managing the global epidemic: report of a WHO Consultation. Geneva: WHO; 2000. 252 p. (WHO technical report series, n. 284).

16. Organización Panamericana de la Salud. Encuesta multicéntrica salud beinestar y envejecimiento (SABE) en América Latina y el Caribe: informe preliminar [Internet]. 36th Reunión del Comité Asesor de Investigaciones em Salud; 2001 Jun 9-11; Kingston, Jamaica. Washington, D.C.: División de Promoción y Protección de la Salud (HPP); Mayo 2001[cited 2018 July 12]. 93 p. Available from: http://envejecimiento. csic.es/documentos/documentos/paho-salud-01.pdf.

17. Kwok A, Palermo C, Boltong A. Dietary experiences and support needs of women who gain weight following chemotherapy for breast cancer. Support Care Cancer. 2015;23(6):1561-8. doi: https://doi.org/10.1007/ s00520-014-2496-5.

18. Ligibel JA, Alfano CM, Courneya KS, et al. American Society of Clinical Oncology position statement on obesity and cancer. J Clin Oncol. 2014;32(31):3568-74. doi: https://doi.org/10.1200/JCO.2014.58.4680.

19. Nissen MJ, Shapiro A, Swenson KK. Changes in weight and body composition in women receiving chemotherapy for breast cancer. Clin Breast Cancer. 2011;11(1):52-60. doi: https://doi.org/10.3816/CBC.2011.n.009.

20. Dieli-Conwright CM, Wong L, Waliany S, et al. An observational study to examine changes in metabolic syndrome components in patients with breast cancer receiving neoadjuvant or adjuvant chemotherapy. Cancer. 2016;122(17):2646-53. doi: https://doi.org/10.1002/ cncr.30104.

21. Lahmann PH, Lissner L, Gullberg B, et al. Sociodemographic factors associated with long-term weight gain, current body fatness and central adiposity in Swedish women. Int J Obes Relat Metab Disord. 2000;24(6):685-94. doi: https://doi.org/10.1038/ sj.ijo.0801219.

22. Caan BJ, Emond JA, Natarajan L, et al. Post-diagnosis weight gain and breast cancer recurrence in women with early stage breast cancer. Breast Cancer Res Treat. 2006;99(1):47-57. doi: https://doi.org/10.1007/s10549006-9179-y.

23. Freedman RJ, Aziz N, Albanes D, et al. Weight and body composition changes during and after adjuvant chemotherapy in women with breast cancer. J Clin Endocrinol Metab. 2004;89(5):2248-53. doi: https:// doi.org/10.1210/jc.2003-031874.

24. de Vries YC, van den Berg MMGA, de Vries JHM, et al. Differences in dietary intake during chemotherapy 
in breast cancer patients compared to women without cancer. Support Care Cancer. 2017;25(8):2581-91. doi: https://doi.org/10.1007/s00520-017-3668-x.

25. Steinbach S, Hummel T, Böhner C, et al. Qualitative and quantitative assessment of taste and smell changes in patients undergoing chemotherapy for breast cancer or gynecologic malignancies. J Clin Oncol. 2009;27(11):1899-905. doi: https://doi.org/10.1200/ JCO.2008.19.2690.

26. Kuba S, Fujiyama R, Yamanouchi K, Morita M, Sakimura C, Hatachi T, et al. Awareness of dysgeusia and gustatory tests in patients undergoing chemotherapy for breast cancer. Support Care Cancer. 2018;26(11):38839. doi: https://doi.org/10.1007/s00520-018-4256-4.

27. Gamper EM, Zabernigg A, Wintner LM, et al. Coming to your senses: detecting taste and smell alterations in chemotherapy patients. A systematic review. J Pain Symptom Manage. 2012;44(6):880-95. doi: https://doi. org/10.1016/j.jpainsymman.2011.11.011.

28. De Laurentiis M, Bonfadini C, Lorusso V, et al. Incidence of nausea and vomiting in breast cancer patients treated with anthracycline plus cyclophosphamide-based chemotherapy regimens in Italy: NAVY observational study. Support Care Cancer. 2018;26(1):4021-9. doi: : https://doi.org/10.1007/s00520-018-4259-1.

29. Wang XS, Zhao F, Fisch MJ, et al. Prevalence and characteristics of moderate to severe fatigue: a multicenter study in cancer patients and survivors. Cancer. 2014;120(3):425-32. doi: https://doi.org/10.1002/ cncr. 28434 .

30. Reinertsen KV, Cvancarova M, Loge JH, et al. Predictors and course of chronic fatigue in long-term breast cancer survivors. J Cancer Surviv. 2010;4(4):405-14. doi: https://doi.org/10.1007/s11764-010-0145-7.

31. Gerber LH, Stout N, McGarvey C, et al. Factors predicting clinically significant fatigue in women following treatment for primary breast cancer. Support Care Cancer. 2011;19(10):1581-91. doi: https://doi. org/10.1007/s00520-010-0986-7.

32. World Cancer Research Fund; American Institute for Cancer Research; Continuous Update Project Report. Diet, nutrition, physical activity, and the breast cancer. London: WCRF; 2017. [revised 2018; cited 2018 July 12]. Available from: http://www.aicr.org/continuousupdate-project/reports/breast-cancer-report-2017.pdf.

33. Thomson ZO, Reeves MM. Can weight gain be prevented in women receiving treatment for breast cancer? A systematic review of intervention studies. Obes Rev. 2017;18(11):1364-73. doi: https:/doi. org/10.1111/obr.12591.

34. Furmaniak AC, Menig M, Markes MH. Exercise for women receiving adjuvant therapy for breast cancer. Cochrane Database Syst Rev. 2016 Sep;9:CD005001. doi: https://doi.org/10.1002/14651858.
35. Mefferd K, Nichols JF, Pakiz B, et al. A cognitive behavioral therapy intervention to promote weight loss improves body composition and blood lipid profiles among overweight breast cancer survivors. Breast Cancer Res Treat. 2007;104(2):145-52. doi: https://doi. org/10.1007/s10549-006-9410-x. 